\title{
Redesign the User Interface of the Purwakarta Disdukcapil Mobile Application Using Kansei Engineering \\ Yudhi Raymond Ramadhan ${ }^{1 *}$, Imam Maruf Nugroho ${ }^{2)}$, Imam Khaerul Anwar ${ }^{3)}$ \\ ${ }^{122) 33}$ STT. Wastukancana, Indonesia \\ 1)yudhi@stt-wastukacana.ac.id, 2) imam.ma@stt-wastukancana.ac.id, ${ }^{3)}$ imam17anwar@gmail.com
}

Submitted: xxxxx | Accepted: xxxx | Published: xxxxx

\begin{abstract}
The function and usability of a mobile application are the main reasons for making the application. In addition, the User Interface (UI) design factor is also an important consideration in making a mobile application. Good UI design is the main attraction for the application to use. There are many ways to make a good UI design. Kansei Engineering (KE) is one of the methods that can be used in the UI design process. Since the creation of the Mobile Disdukcapil application, there has never been a study on the application's design interface. This research aims to make recommendations on design elements desired by users. The KE method can detect the user's feelings towards an interface. So that the KE method will produce a UI design for the Disdukcapil mobile application that is liked by the user. The methodology used refers to the Kansei Engineering Type I methodology. This research uses Kansei Words to represent the emotional factors of the user when viewing a product specimen. Kansei Word used as many as 10 words related to the UI display on the mobile application. The mobile application specimens used were 5 specimens, which were taken from various similar applications. This study involved 80 participants to fill out the questionnaire. The results of the questionnaire were processed using multivariate statistical analysis, namely Cronbach's Alpha, Coefficient Correlation Analysis (CCA), Principal Component Analysis (PCA), Factor Analysis (FA), and Partial Least Square (PLS). The results of this study are in the form of recommendations for UI design elements based on the most dominant emotional factors. Based on the results of data processing, the dominant emotional factors are "Colorful" and "Simple".
\end{abstract}

Keywords: Disdukcapil Mobile Application, Kansei Engineering, Kansei Engineering Type I, Kansei Word, User Interface.

\section{INTRODUCTION}

The Smartphone is one of the information technology devices that is growing very rapidly at this time. There are various types of mobile applications on smartphones that can be used to help humans work. Among them are information media for a company or industry profits, government services, product sales, and so on. The function and usability of a mobile application is the main reason for making the application. In addition to function and usability, the User Interface (UI) design factor is also a consideration in making a mobile application. Good UI design is the main attraction for the application to be used. A mobile application must have an element of comfort and convenience when operated. So, users often judge not only from its function but from the UI of the application. If the interface design is not good, then that will be one of the reasons for not using the application. Many ways can be done to create a nice and attractive UI design

Dinas Kependudukan dan Pencatatan Sipil (Disdukcapil) of Purwakarta is a government agency in Purwakarta that utilizes mobile applications to support all information needs related to the services of Disdukcapil Purwakarta. This mobile application is to facilitate the public in accessing information about the population. The Purwakarta Disdukcapil Mobile Application is one of the mobile applications that has been completed, but there has been no research on user opinions. At Disdukcapil Purwakarta, each application development will be managed by the Data Utilization and Service Innovation Division. The results of this research will later be used for the development of the next Purwakarta Disdukcapil mobile application. For now, there is no innovation related to the development of this mobile application in the Data Utilization and Service Innovation Sector. Based on this information, *Corresponding author 
researchers will develop from the side of the mobile application display according to the wishes and interests of the user using the Kansei Engineering method.

Kansei Engineering (KE) is one of the methods that can be used in the UI design development process. The KE method can detect the user's feelings towards a display. KE is a method for realizing a particular product design based on a systematic exploration of human feelings and senses (sight, touch, smell, hearing, taste) (Nagamachi \& Lokman, 2015)

\section{Kansei Engineering (KE)}

\section{LITERATURE REVIEW}

According to the Japanese dictionary, Kansei means sensitivity (Syaifoelida et al., 2013). Kansei involves sensitivity, sensibility, feelings, and emotions that are harmonized through the six senses, namely eyesight, hearing, smell, touch, taste, Internal receptor. (Nagamachi \& Lokman, 2015). Figure 1 is an illustration of Kansei's creation

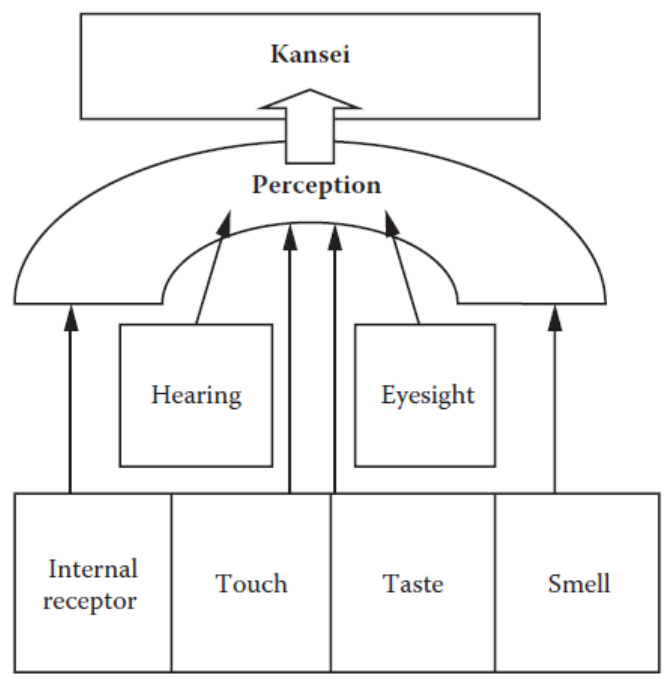

Figure 1 Kansei’s creation (Nagamachi \& Lokman, 2015)

Kansei is then translated into an engineering method called Kansei Engineering. This method was first introduced by Mitsuo Nagamachi (Dean of Hiroshima International University) as a new engineering method in the design and development of human-oriented industrial products (Lokman, 2010). KE is a technology for developing products that combine the disciplines of psychology and engineering. This method was developed by Professor Mitsuo Nagamachi in the early 1970s in Japan and has been used by many companies in Japan (Suhaimi \& Lokman, 2018). The main reason for using KE is to gain knowledge about Kansei's responses and the indicators that influence those responses and to embed that knowledge into the design of innovative new products/services (Lokman et al., 2020). Figure 2 shows the working principle of KE.

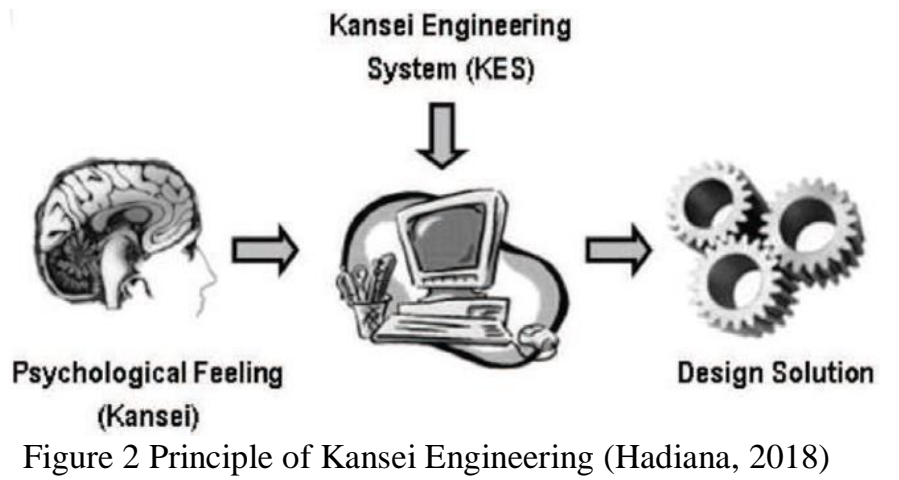

\section{Kansei Engineering Type I: KEPack}

Kansei Engineering Type I is the most popular Kansei technique. The characteristic of KEPack is to make the design concept of a product into several design concepts, then each concept is broken down again into design sub-

*Corresponding author 
concepts (Lokman et al., 2013). The process of making the design concept is in one of the KEPack process flows. The KEPack process flow consists of 10 stages. Figure 3 illustrates the flow of the KEPack process.

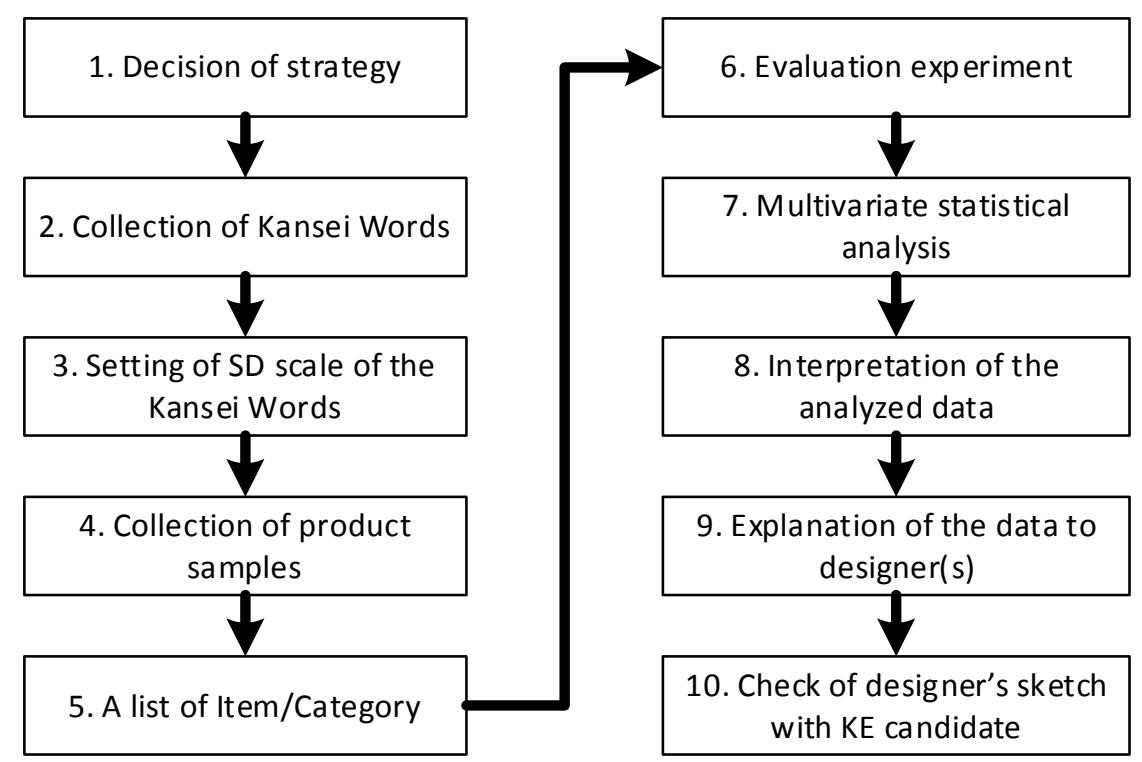

Figure 3 KEPack Methodology (Hadiana, 2018)

\section{Kansei Word}

Kansei Word (KW) in the form of keywords related to human emotional or affective (Taharim et al., 2016). Determining KW greatly influences the success of Kansei's research. Kansei words are used to represent emotional responses and are synthesized based on journals, magazines, brainstorming sessions, design guidebooks, and related literature on comfort, with words expressing sensitivity and emotion. (Bidin \& Lokman, 2018).

\section{Multivariate Statistical Analisis}

The Multivariate statistical analysis used in this research is described below:

\section{Cronbach's Alpha}

Cronbach's Alpha is a method that is useful for measuring the level of data reliability. The data is said to be reliable if the results of the Cronbach's Alpha analysis have a value above 0.7, so the data can be used for further multivariate analysis calculations (Ginanjar \& Supendi, 2018; Hadiana \& Ginanjar, 2018; Ma'ruf Nugroho et al., 2019; Ramadhan, 2018).

\section{Correlation Coefficient Analysis (CCA)}

CCA analysis was used to measure the strength of the relationship between each Kansei Word (Ginanjar \& Supendi, 2018; Hadiana \& Ginanjar, 2018; Ma'ruf Nugroho et al., 2019; Ramadhan, 2018).

\section{Principal Component Analysis (PCA)}

PCV is used to visualize direction and strength of emotion over the structure of emotion and determine The Kansei area (Ginanjar \& Supendi, 2018; Hadiana \& Ginanjar, 2018; Ma'ruf Nugroho et al., 2019; Ramadhan, 2018).

\section{Factor Analysis (FA)}

FA is useful for finding significant factors from Kansei Word (Tsuchiya et al., 2018) and to support the results of PCA calculations (Ginanjar \& Supendi, 2018; Hadiana \& Ginanjar, 2018; Ma'ruf Nugroho et al., 2019; Ramadhan, 2018).

\section{Partial Least Square (PLS)}

We use PLS to translate the relationship of influence between emotions and design elements, so it produces recommendations for design elements according to the emotions obtained in the previous stage (Ginanjar \& Supendi, 2018; Hadiana \& Ginanjar, 2018; Ma'ruf Nugroho et al., 2019; Natalia et al., 2020; Ramadhan, 2018).

*Corresponding author 


\section{METHOD}

The methodology used in this study refers to KEPack. Figure 4 describes the research methodology carried out.

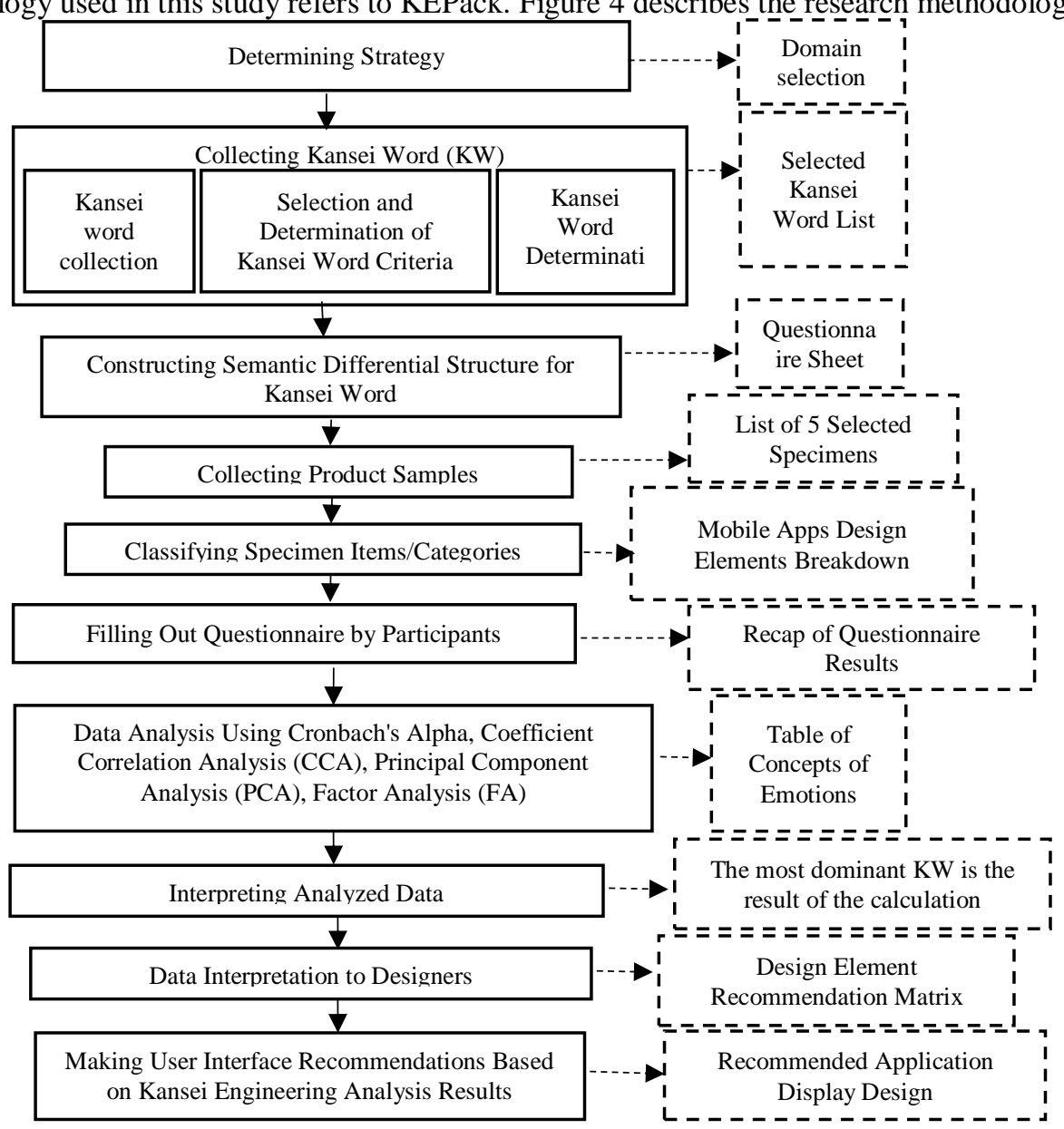

Figure 4 Research Methodology

\section{Define Strategy}

The initial stage of this research is to determine the strategy by selecting the research domain. The domain of this research is the Purwakarta Disdukcapil Mobile Application, which is implemented in Purwakarta Regency. The Department of Population and Civil Registration (Disdukcapil) of Purwakarta Regency is the Office that is responsible and directly under the Regent. Population data is one of the indicators for determining the development policy of an area which includes population biodata. This data is used as consideration in determining the policies to be implemented in the region. Disdukcapil Purwakarta released a mobile application to assist the community in facilitating information services about population data in the Purwakarta Regency area.

\section{Collecting Kansei Word}

The second stage is to collect Kansei Word (KW) which will be used as material for preparing the questionnaire. $\mathrm{KW}$ is obtained from several references such as dictionaries, magazines, research related to mobile applications, expert opinions which are then linked to the object under study. This stage will produce a list of selected KW.

\section{Constructing Semantic Differential Structure for Kansei Word}

After the KW selection process, the next step is to make a questionnaire with 5 levels of the Semantic Differential (SD) scale. This questionnaire will be used to measure the user's feelings when viewing a specimen of an existing mobile application UI.

\section{Collecting Product Samples}

At this stage, collect Disdukcapil mobile applications from various regions on the Google Playstore. After getting various applications, they will be filtered by looking at the similarities in the appearance of the application. 


\section{Classifying Items/Categories}

The next step is to create an item/category classification table from the design elements of all specimens. This table is used for the multivariate statistical analysis process

\section{Filling Out Questionnaire by Participants}

This stage explains the process of collecting data from participants who fill out the questionnaire. This stage produces a recap of the questionnaire data that will be used for further data processing

\section{Data analysis}

From the results of data collection through questionnaires, the next stage is data processing using multivariate statistics using Cronbach's Alpha, Correlation Coefficient Analysis (CCA), Principal Component Analysis (PCA), and Factor Analysis (FA). This processing will produce a table of the Concept of Emotions.

\section{Interpreting Analyzed Data}

This emotional concept table will produce the most dominant $\mathrm{KW}$, which will later be used to determine design elements using PLS calculations.

\section{Data Interpretation To Designers}

Based on the results of the PLS calculations, a design concept recommendation matrix is made. This design concept recommendation will be a reference for making the next Purwakarta Disdukcapil mobile application UI.

\section{Making User Interface Recommendations Based on Kansei Engineering Analysis Results}

The last stage of this research is to make a UI design recommendation for the Purwakarta Disdukcapil mobile application based on the results of Kansei Engineering's analysis.

\section{RESULT}

This research produces recommendations for the UI display design of the Disdukcapil mobile application. From the results of the KE analysis, 2 recommendations for the UI display design of the Disdukcapil mobile application were taken with a simple and colorful design concept. Table 1 is Colourful Design Concepts and Sederhana (Simple) Design Concepts.

Table 1 UI recommendation from Kansei Engineering Implementation

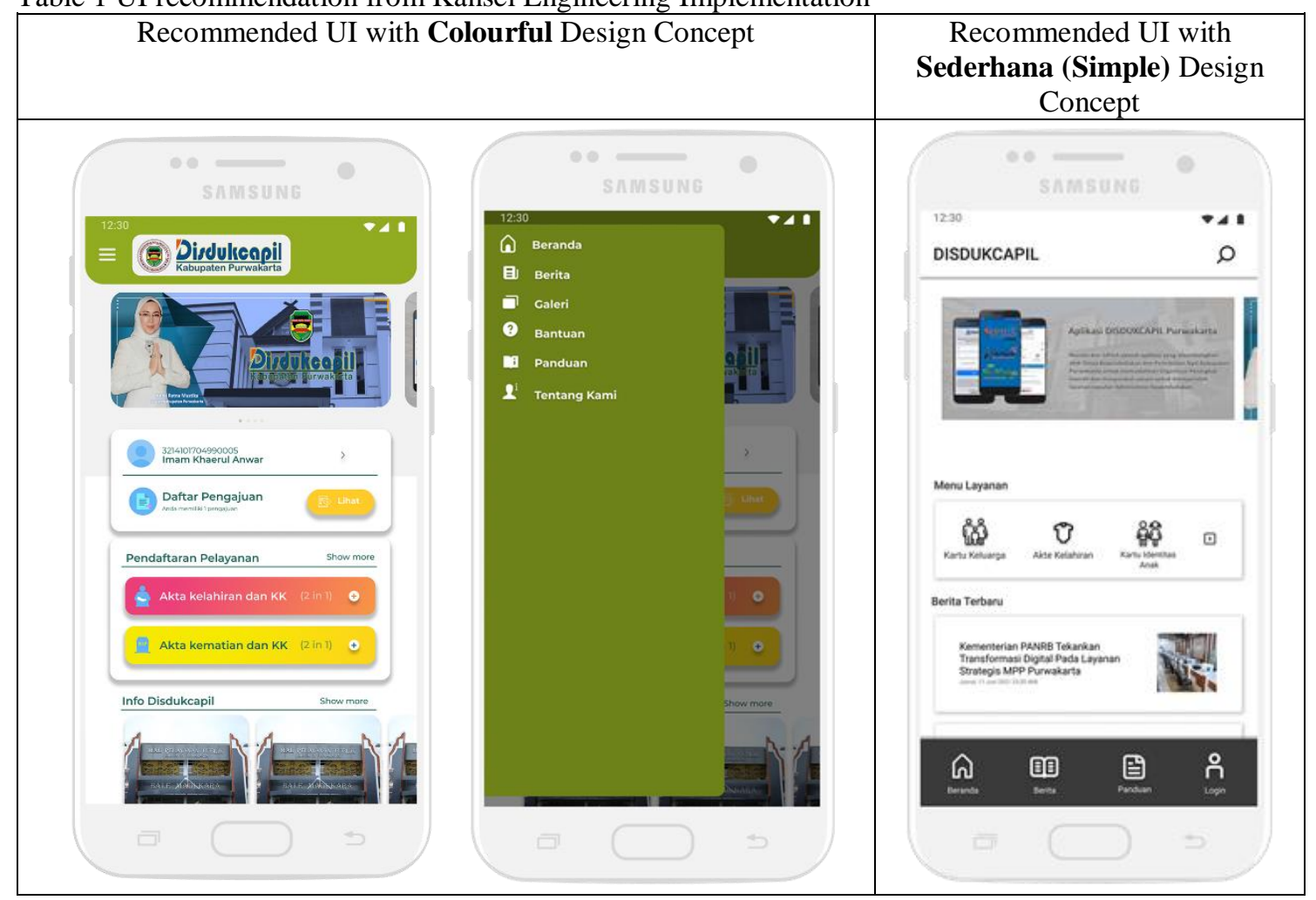

*Corresponding author 


\section{Kansei Word Selection Process}

\section{DISCUSSIONS}

At the beginning of the word search to be implemented in KW, 30 words were found which were estimated to represent the expression of feelings towards the specimen from each participant. From the $30 \mathrm{KW}$, a selection was made by taking one of several KWs that had similar meanings and also selecting KWs that had meanings related to the Purwakarta Disdukcapil Mobile Application. After going through the selection process, the selected KW candidates will be used in a questionnaire using the SD scale. The results of the selection can be seen in table 2:

Table 2 Kansei Word Selection Results

\begin{tabular}{|c|c|l|}
\hline No. & Kansei Word & \multicolumn{1}{c|}{ Description } \\
\hline 1. & $\begin{array}{c}\text { Dinamis } \\
\text { (Dynamic) }\end{array}$ & $\begin{array}{l}\text { Not boring, the display makes users want to use the application with longer } \\
\text { time }\end{array}$ \\
\hline 2. & $\begin{array}{c}\text { Menarik } \\
\text { (Interesting) }\end{array}$ & Give effects like, happy in using the application \\
\hline 3. & Futuristic & Gives a modern and sophisticated impression. \\
\hline 4. & $\begin{array}{c}\text { Sederhana } \\
\text { (Simple) }\end{array}$ & Give the impression of what it is and not excessive. \\
\hline 5. & $\begin{array}{c}\text { Colorful } \\
\text { (Match) }\end{array}$ & Full of color, so the application looks more color variations \\
\hline 7. & $\begin{array}{c}\text { Nyaman } \\
\text { (Comfortable) }\end{array}$ & Selection of colors that make it comfortable to see. \\
\hline 8. & $\begin{array}{c}\text { Cerah } \\
\text { (Bright) }\end{array}$ & Use one or a combination of bright colors. \\
\hline 9. & $\begin{array}{c}\text { Unik } \\
\text { (Unique) }\end{array}$ & Gives a different impression from the others \\
\hline 10. & \begin{tabular}{c} 
Elegant \\
\hline
\end{tabular} & Creates a beautiful, neat, and cool impression. \\
\hline
\end{tabular}

\section{Constructing Semantic Differential Structure for Kansei Word}

A total of 10 Kansei Words that have been identified will then be compiled and used on an SD scale for questionnaires which will be distributed to participants. An example of an SD scale questionnaire that will be distributed can be seen in Table 3

Table 3 Semantic Differential (SD) Kansei Word for questionnaires

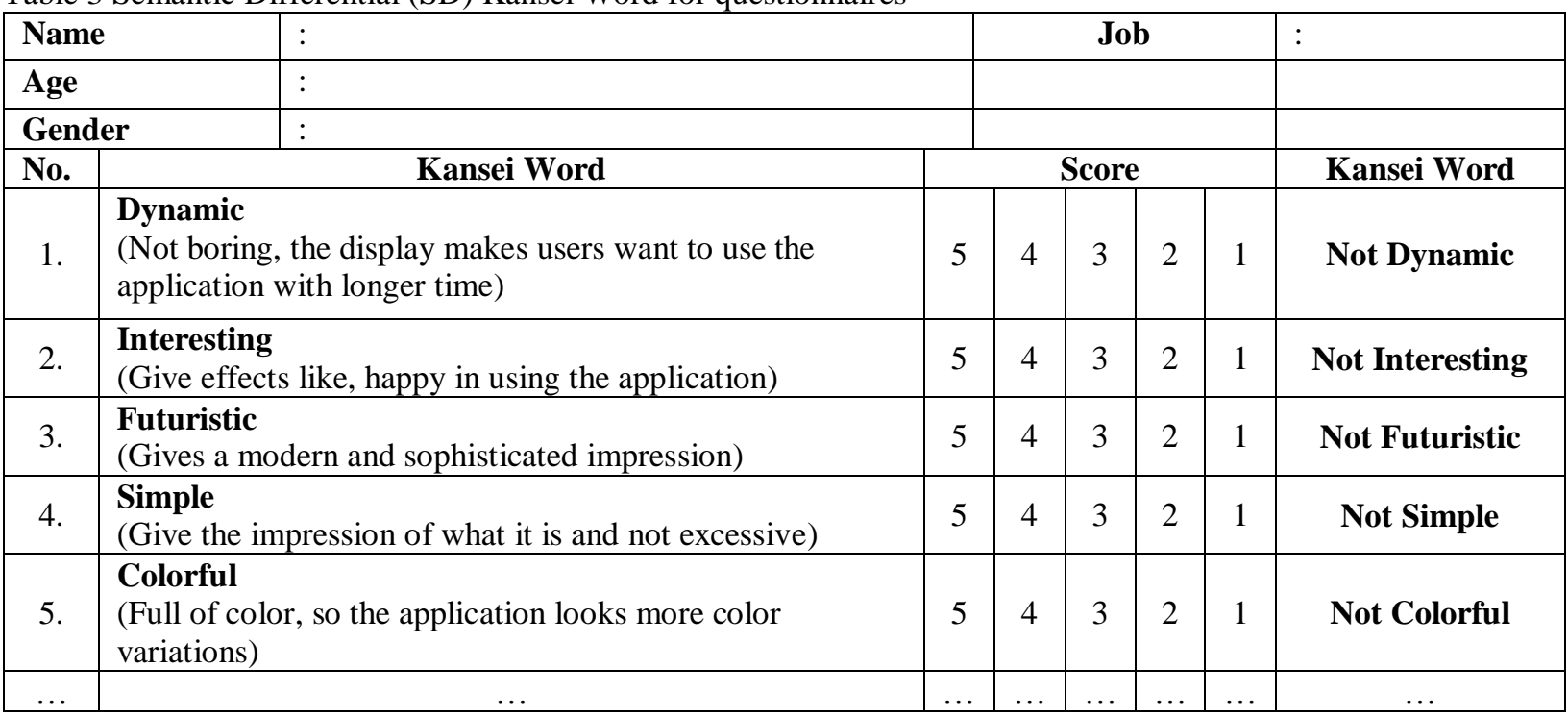

\section{Collecting Product Samples}

*Corresponding author 
The results of the specimen selection process selected 5 samples of specimens, each of which is unique, these five specimens can be seen in table 4

Table 4 Specimen List

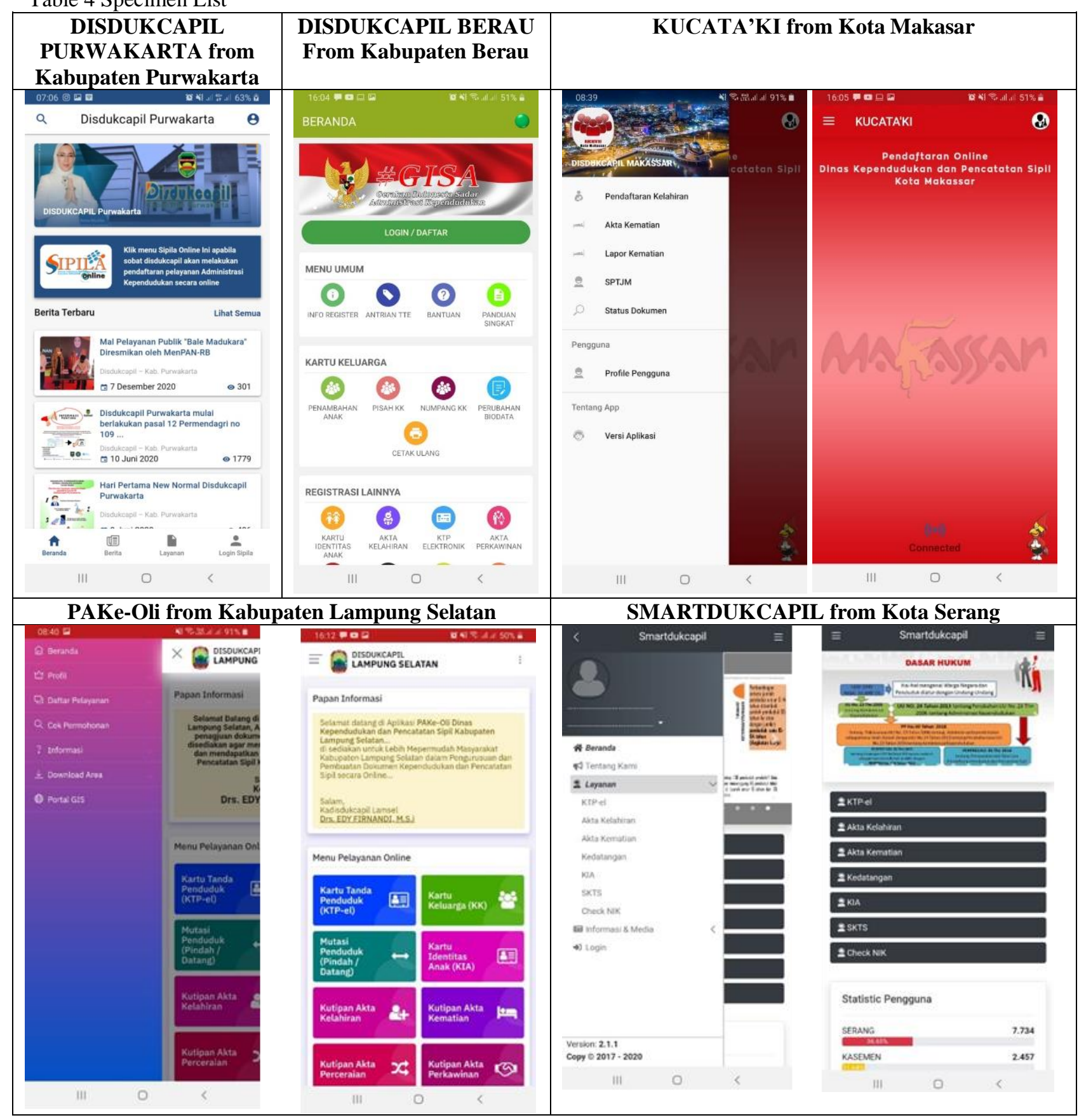

\section{Data Analysis}

Cronbach's Alpha

The first analysis is Cronbach's Alpha which is useful for measuring data reliability. From the results of the calculation of Cronbach's Alpha, a value of 0.9841 is obtained. The resulting value is above 0.7 . This means that the data is reliable and can be continued for the next analysis process.

Correlation Coefficient Analysis (CCA)

*Corresponding author 
The next analysis is Coefficient Correlation Analysis (CCA) which is useful for measuring the strength of the relationship between each Kansei Word (KW). Table 5 below is the result of The CCA analysis.

Table 5 Result of CCA

\begin{tabular}{|c|c|c|c|c|c|c|c|c|c|c|}
\hline Variables & Dynamic & Interesting & Futuristic & Simple & Colorful & Match & Comfortable & Bright & Unique & Elegant \\
\hline Dynamic & 1 & 0.9863 & 0.9667 & 7127 & 0.9375 & 9206 & 0.8951 & 9153 & .8835 & 0.9595 \\
\hline Interesting & 9863 & 1 & 9256 & 303 & 795 & 9435 & & 8368 & 484 & 0.9834 \\
\hline Futu & 9667 & 9256 & 1 & 0.7013 & 9612 & 9152 & & 9606 & 9248 & 0.9223 \\
\hline Simple & 127 & & & 1 & 0.5163 & 0.9228 & & 4800 & 0.6013 & 0.8729 \\
\hline & 375 & & 0.9612 & 0.5163 & 1 & 0.8050 & & 9747 & 0.9560 & 0.8428 \\
\hline Match & 9206 & & .9152 & 0.9228 & & 1 & .9826 & 7689 & 0.8376 & 0.9867 \\
\hline Comfortable & 3951 & 9448 & 8459 & 0.9390 & 0.7305 & 0.9826 & 1 & 0.6773 & 0.7655 & 0.9829 \\
\hline Bright & 153 & 368 & 0.9606 & 0.4800 & 0.9747 & 0.7689 & & 1 & 0.8842 & 0.7954 \\
\hline & & & 0.9248 & & 0.9560 & 0.8376 & 0.7655 & 0.8842 & 1 & 0.8529 \\
\hline Elegant & 0.9595 & 0.9834 & 0.9223 & 0.8729 & 0.8428 & 0.9867 & 0.9829 & 0.7954 & 0.8529 & \\
\hline
\end{tabular}

Principal Component Analysis (PCA)

PCA is used to describe the direction and dominance of the research data variables, namely $\mathrm{KW}$, and specimens. Figure 5 is one of the PC vector days of PCA calculations. The red dots show the distribution of the user's emotions $(\mathrm{KW})$ towards the specimen. Subjectively, it can be said that the group of specimens in the positive $\mathrm{x}$-axis zone is a group of specimens considered by the participants to have a favorable appearance, while the group of specimens in the negative $\mathrm{x}$-zone is a group of specimens considered by the majoring participants to have a less favorable appearance.

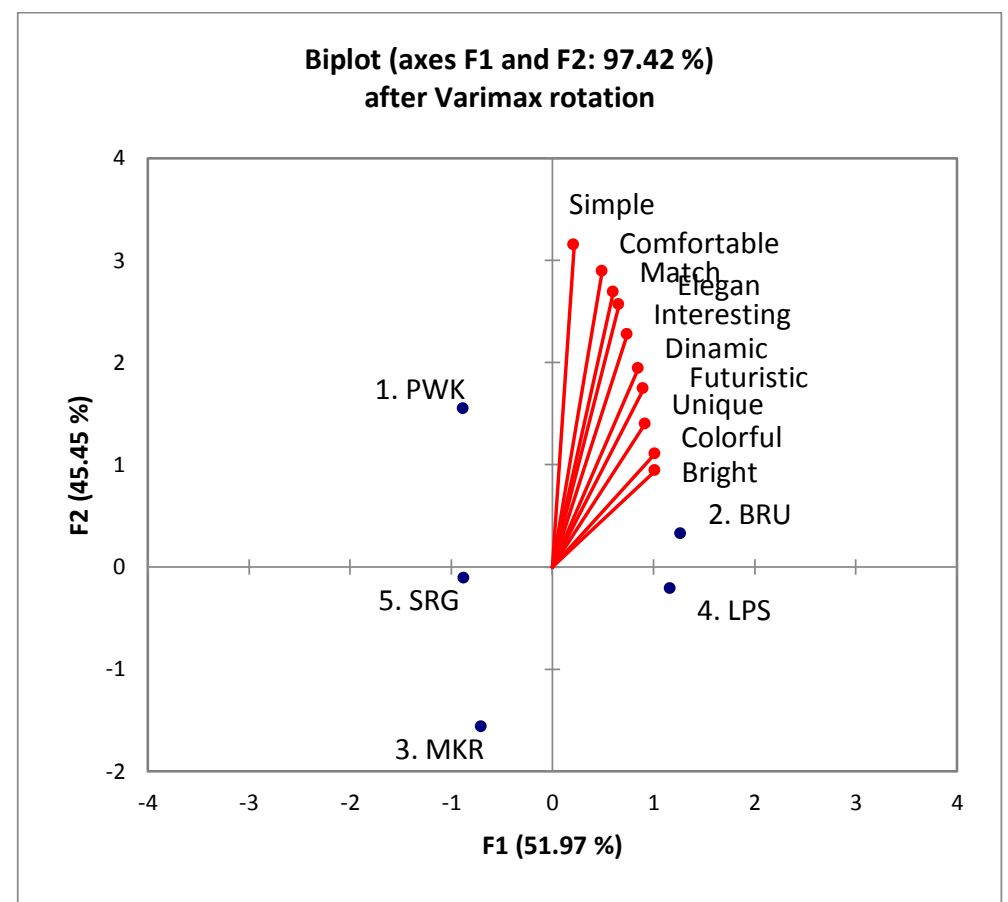

Factor Analysis (FA)

Figure 5 Result of PC Vector F1 and F2

The result of the next stage is the process of analyzing the data using Factor Analysis (FA). This analysis aims to strengthen the results of the previous analysis, namely Principal Component Analysis (PCA), and use varimax rotation so that the results obtained are more accurate. The results of the FA calculation can be seen in Table 6 below.

Table 6 FA Based Emotion Concepts

*Corresponding author 


\begin{tabular}{|l|c|l|c|}
\hline Kansei Word & D1 & Kansei Word & D2 \\
\hline Simple & 0.2077 & Bright & 0.3002 \\
\hline Comfortable & 0.4448 & Colorful & 0.3416 \\
\hline Match & 0.5504 & Unique & 0.4496 \\
\hline Elegant & 0.6046 & Futuristic & 0.5398 \\
\hline Interesting & 0.6783 & Dynamic & 0.6014 \\
\hline Dynamic & $\mathbf{0 . 7 8 0 8}$ & Interesting & $\mathbf{0 . 6 9 9 2}$ \\
\hline Unique & $\mathbf{0 . 8 1 6 1}$ & Elegant & $\mathbf{0 . 7 9 5 3}$ \\
\hline Futuristic & $\mathbf{0 . 8 3 1 2}$ & Match & $\mathbf{0 . 8 3 3 7}$ \\
\hline Bright & $\mathbf{0 . 9 3 2 5}$ & Comfortable & $\mathbf{0 . 8 9 5 6}$ \\
\hline Colorful & $\mathbf{0 . 9 3 9 9}$ & Simple & $\mathbf{0 . 9 4 5 1}$ \\
\hline
\end{tabular}

\section{Interpreting Analyzed Data}

The emotional concept that has been generated from PCA and FA will then be translated into design elements using Partial Least Square (PLS). The purpose of this process is to find out the design elements that greatly affect the participants' emotions. The results of this process will serve as a reference for the recommendation of design elements following the emotional goals of the participants. From the results of the PLS calculations, a design element recommendation reference is made which can be seen in table 7

Table 7 Design element recommendation reference

\begin{tabular}{|c|l|l|l|c|}
\hline \multicolumn{2}{|c|}{ Kansei Word Colorful } & \multicolumn{2}{c|}{ Kansei Word Simple } \\
\hline \multirow{2}{*}{ No } & \multicolumn{2}{|c|}{$\begin{array}{c}\text { Average Range } \\
\mathbf{0 . 0 8 3 6}\end{array}$} & \multicolumn{1}{|c|}{ Category } & $\begin{array}{c}\text { Average Range } \\
\mathbf{0 . 0 6 9 0} \\
\text { Range }\end{array}$ \\
\cline { 3 - 5 } & & 0.1541 & Nav Bar Logo & 0.1306 \\
\hline 1 & Body Menu Color & 0.1310 & Body Background Color & 0.1306 \\
\hline 2 & Header Profile Icon Position & 0.1310 & Header BG Color & 0.1180 \\
\hline 3 & Body Menu & 0.1269 & Header Search & 0.1134 \\
\hline 4 & Header BG Color & 0.1268 & Header Text Color & 0.1055 \\
\hline 5 & Nav Bar Font Color & 0.1268 & Header Nav Bar & 0.1012 \\
\hline 6 & Nav Bar Icon Color & 0.1050 & Header Nav Bar Position & 0.1012 \\
\hline 7 & Footer Menu & 0.1017 & Body Font Color & 0.1012 \\
\hline 8 & Header Logo & 0.0975 & Footer Menu & 0.0992 \\
\hline 9 & Nav Bar Profile Icon & 0.0886 & Body Slider & 0.0937 \\
\hline 10 & Nav Bar Logo & 0.0886 & Body Content Border & 0.0937 \\
\hline 11 & Body Background Color & 0.0764 & Nav Bar Font Color & 0.0650 \\
\hline 12 & Body Menu Shape & 0.0718 & Nav Bar Icon Color & 0.0650 \\
\hline 13 & Header Search & 0.0689 & Footer Menu BG Color & 0.0528 \\
\hline 14 & Header Nav Bar & 0.0689 & Header Logo & 0.0159 \\
\hline 15 & Header Nav Bar Position & 0.0689 & Body Menu Color & 0.0154 \\
\hline 16 & Body Font Color & 0.0655 & Header Profile Icon Position & 0.0140 \\
\hline 17 & Body Menu Icon Color & 0.0244 & Body Menu & 0.0140 \\
\hline 18 & Header Text Color & 0.0122 & Nav Bar Profile Icon & 0.0092 \\
\hline 19 & Footer Menu BG Color & 0.0107 & Body Menu Icon Color & 0.0070 \\
\hline 20 & Body Slider & 0.0107 & Body Menu Shape & 0.0026 \\
\hline 21 & Body Content Border & & & \\
\hline
\end{tabular}

\section{CONCLUSION}

This research has implemented Kansei Engineering in the process of redesigning the user interface of the mobile application Disdukcapil Purwakarta. Kansei Word used as many as 10 words and specimens of the Disdukcapil mobile application used as many as 5 specimens resulted in 21 categories of design elements. This study involved 80 participants. Data processing uses multivariate statistics, namely Cronbach's Alpha, CCA, PCA, and the results from PCA are then strengthened by the results of Factor Analysis (FA) calculations. There are two *Corresponding author 
emotional factors that affect the user interface design of the Mobile Application Disdukcapil Purwakarta using the Kansei Engineering approach, namely "Colorful" and "Simple". The results of the application of the Kansei Engineering method in making the user interface design recommendations are in the form of a design element recommendation matrix obtained from PLS calculations. From the results of the design recommendations obtained, an interface design simulation was made.

\section{REFERENCES}

Bidin, S. A. H., \& Lokman, A. M. (2018). Enriching the Comfortability Emotion on Website Interface Design Using Kansei Engineering Approach. Proceedings of the 7th International Conference on Kansei Engineering and Emotion Research, 739, 792-800. https://doi.org/10.1007/978-981-10-8612-0_82

Ginanjar, A., \& Supendi, Y. (2018). Implementasi Kansei Engineering dalam Perancangan Antarmuka Website Mobile Portal Berita Informasi Pendidikan dan Kesehatan Anak. 14(1). https://doi.org/10.32816/tiarsie.v14i1.18

Hadiana, A. (2018). Analysis Learners' Preference in E-Learning System Using Kansei Approach. In IntechOpen. InTech. https://doi.org/10.5772/intechopen.75620

Hadiana, A., \& Ginanjar, A. (2018). Designing Interface of Mobile Parenting Information System Based on User's Perception Using Kansei Engingeering. Journal of Data Science and Its Applications, 1(1), 10-19. https://doi.org/10.21108/jdsa.2018.1.7

Lokman, A. M. (2010). DESIGN \& EMOTION: THE KANSEI ENGINEERING METHODOLOGY. Malaysian Journal of Computing (MJoC), 1(1), 1-14. https://ir.uitm.edu.my/id/eprint/11102/

Lokman, A. M., Haron, M. B. C., Abidin, S. Z. Z., Khalid, N. E. A., \& Ishihara, S. (2013). Prelude to Natphoric Kansei Engineering Framework. Journal of Software Engineering and Applications, 06(12), 638-644. https://doi.org/10.4236/jsea.2013.612076

Lokman, A. M., Ismail, N. N. N. N., \& Hadiana, A. (2020). Kansei Engineering in Malaysia and Indonesia: A Systematic Literature Review. Proceedings of the 8th International Conference on Kansei Engineering and Emotion Research, 1256 AISC, 115-126. https://doi.org/10.1007/978-981-15-7801-4_12

Ma'ruf Nugroho, I., Hadiana, A., \& Singasatia, D. (2019). Design of Wastu Mobile Interface Using Kansei Engineering. Fourth International Conference on Informatics and Computing (ICIC), 1-8. https://doi.org/10.1109/ICIC47613.2019.8985955

Nagamachi, M., \& Lokman, A. M. (2015). Kansei Innovation Practical Design Applications for Product and Service Development. CRC Press Taylor \& Francis Group.

Natalia, N., Sukarsa, Purnama, E. D., \& Ma'sum, A. (2020). Kajian E-Learning Berdasarkan Persepsi Pengguna Menggunakan Kansei Engineering dan Analytical Hierarchy Process. JTERA (Jurnal Teknologi Rekayasa), 5(1), 159-166. https://doi.org/10.31544/jtera.v5.i1.2020.159-166

Ramadhan, Y. R. (2018). Implementasi Kansei Engineering Dalam Desain Tampilan Website Perguruan Tinggi. Jurnal Teknologi Rekayasa, 3(1), 71. https://doi.org/10.31544/jtera.v3.i1.2018.71-78

Suhaimi, A. N. M., \& Lokman, A. M. (2018). A Kansei Approach to Investigate Mobile Apps Requirements for Muslim Women Tourist. Proceedings of the 7th International Conference on Kansei Engineering and Emotion Research, 739, 113-120. https://doi.org/10.1007/978-981-10-8612-0_13

Syaifoelida, F., Yahaya, Sihombing, H., \& Yuhazri. (2013). 2013 - Fevi S, Yahaya, Haeryip S, Yuhazri. KANSEI ENGINEERING THE KE'S PACKAGE REVIEW. GLOBAL ENGINEERS \& TECHNOLOGISTS REVIEW, 3(5), 8-20. https://issuu.com/mr_pixie/docs/getview_vol.3_no.5

Taharim, N. F., Lokman, A. M., \& Isa, W. A. R. W. M. (2016). Emotion and Playful Elements in Mobile Learning. 10th International Conference on Next Generation Mobile Applications, Security and Technologies (NGMAST), 72-76. https://doi.org/10.1109/NGMAST.2016.23

Tsuchiya, T., Lokman, A. M., Kadir, A. S., \& Noordin, F. (2018). Happiness Index Measurement: Application of Kansei Engineering and Positive Psychology. Proceedings of the 7th International Conference on Kansei Engineering and Emotion Research 2018, 739, 855-862. https://doi.org/10.1007/978-981-10-8612-0_89 